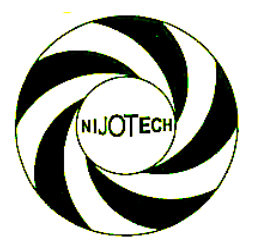

Nigerian Journal of Technology (NIJOTECH)

Vol. 38, No. 3, July 2019, pp. 603 - 608

Copyright@ Faculty of Engineering, University of Nigeria, Nsukka,

Print ISSN: 0331-8443, Electronic ISSN: 2467-8821

http://dx.doi.org/10.4314/njt.v38i3.9

\title{
STABILIZATION OF LATERITIC SOILS WITH ASPHALT- EMULSION
}

\author{
B. D. Oluyemi-Ayibiowu* \\ Dept. of Civil and Environmental EngR'G, Federal Univ. of TeChnology, AkURe, Ondo State, Nigeria \\ E-mail address: bayibiowu@yahoo.com
}

\begin{abstract}
Over the years, soil improvement techniques by chemical additives have provided challenges to highway technology. In this respect, an experimental investigation was undertaken to study the response of three selected lateritic soil samples to stabilization with asphalt-emulsion. The investigation was aimed at providing more solutions to the problems of highway construction and maintenance with the current widespread highway pavement failures in Nigeria. Test results show that lateritic soils respond favourably with the addition of asphalt-emulsion, but materials containing excessive amounts of clay are not found suitable for stabilizing with asphalt-emulsion due to difficulty in mixing and a prolonged curing period needed to obtain desired strength. The best soil-asphalt emulsion mix for the tested soil samples was between 6 and $8 \%$ depending on the plasticity of the soil.
\end{abstract}

Keywords: Lateritic soils, Asphalt Emulsion, Stabilization, California Bearing Ratio (CBR), Unconfined Compressive Strength (UCS), Optimum Moisture Content (OMC), Maximum Dry Density (MDD)

\section{INTRODUCTION}

Laterites are traditional road and building construction materials which are available in most parts of the world. Naturally, lateritic soils vary in composition and characteristics from place to place. Some are directly suitable while some are unsuitable depending on the amount of clay in them. The harder ones are good as subgrade for airfield and highway pavements, while the softer types are good for subbase courses [1]. They can be used for earth roads, and when compacted at required moisture content, are capable of supporting heavy traffic.

However, not all lateritic soils encountered on site can be used directly for construction purposes due to their poor strength characteristics. In some cases, potential soil problems can be avoided by choosing another site, or by removing unwanted soil and replacing with desired soil or by adapting the design to the condition on site. In addition, attempts could be made to alter the properties of the existing soil in order to create a new material capable of meeting the requirement of the task at hand [2].
Over the years, stabilization has become a feasible and attractive technique for improving the engineering properties of soils. Stabilized soils have been used in the construction of roads, airports, car parks, earth dams, building foundations and in various other constructions. Some of the stabilization materials include cement, lime, fly ash and bitumen depending on the type of soil and site condition [3].

The use of asphalt emulsion, which is a liquid mixture that contains asphalt cement, water and an emulsifying agent for road construction and maintenance, is not new. Emulsions were first developed in the early 1900s but not until 1920s that emulsion came into being in the United States [4], with use currently receiving wide acceptance by engineers all over the world because of their performance and economic value.

Asphalt emulsion is used in bases, surface work mixes and in recycling. Some of the factors contributing to its employments are that it does not require petroleum solvent to make it liquid and can be used without additional heat, thereby contributing to energy saving.

* Corresponding author, tel: +234-803-354-6221 
It reduces atmospheric pollution because there are little or no hydrocarbon emissions from it. It also has the ability of coating damp aggregate surfaces. They are widely available in variety of types and there is potential cost savings by the use of less fuel [6]. In the United States, attention had been directed to fuel savings by using asphalt emulsion instead of cutback asphalt, whereby a huge amount of petroleum solvents could be saved annually by such substitution [7].

The demand for a well-maintained and efficient highway network continues and consequently, demand for asphalt which is an essential material to meet this requirement continues. Because of these tremendous needs, every attempt should be made to utilize road materials in an efficient and conservative manner. Using asphalt-emulsion will also be beneficial in increasing safety for workers, considering its ability to be handled at lower temperature and its lower flammability. There is also the ability to increase the service life of slightly distressed existing pavements.

Asphalt emulsion is an ideally used to stabilize soils and aggregates. The water in the emulsion mixes easily with the soil, and the cured asphalt increases the material's strength. Also to its credit is the ability of soils stabilized with asphalt emulsion deformation by the forces of traffic and water.

This paper therefore describes a laboratory investigation on the appropriateness and effectiveness of using asphalt emulsion stabilized lateritic soils as a way of improving the strength of locally available ones.

\section{MATERIALS AND METHOD}

To evaluate the effect of soil physical properties on stabilized materials, three representative lateritic soil samples designated as samples A, B and C were used for this investigation. The samples were borrow pit materials collected along Ado-Ekiti - Ikare Akoko road, which is one of the roads linking Ekiti and Ondo State in South-Western Nigeria. Figure 1 shows the map of the study location. The road has suffered incessant failures and this brought about the study of the lateritic materials along the road to assess their suitability or otherwise, and possible improvement with asphalt-emulsion.

The asphalt - emulsion used is a slow setting type called Colax A obtained from Ondo State Asphalt Company Limited, along Akure- Ondo road, Akure, Ondo State Nigeria.

In order to determine the general characteristics of samples and to evaluate their physical properties and effectiveness of asphalt-emulsion stabilized samples, laboratory tests such as natural moisture content, gram size analysis, Atterberg limits, chemical composition, compaction, Unconfined Compressive Strength (UCS) and California Bearing Ratio (CBR) were carried out on the collected soil samples.

To examine the response of soils to varied percentages of the additives, the soil samples were mixed with 2, 4, 6 and $8 \%$ asphalt-emulsion contents after which compaction, CBR and UCS were performed on the stabilized samples. Testing were carried out in accordance with the procedures specified by the [8].

\section{RESULTS AND DISCUSSIONS}

After the samples had been collected and treated, their physical and chemical properties were determined to ensure that when their response to stabilization with asphalt-emulsion was studied, all relevant factors would be available-for establishing correlation between composition and asphalt-emulsion stabilization of the soils.

\subsection{Classification and Identification Tests}

The result of particle size distributions of samples studied is as shown in Table 1. From the Table, sample A has $3.4 \%$ coarse aggregates, $62.4 \%$ sand and $34.2 \%$ fines. Sample B contains $5.8 \%$ coarse aggregates, $62.2 \%$ sand and $32.0 \%$ fines while sample $C$ has $0.5 \%$ coarse aggregate, $44.0 \%$ sand and $55.5 \%$ fines. The Atterbergs test result shows liquid limits of $31 \%, 46 \%$ and $55 \%$ with plasticity indices of $9 \%, 15 \%$ and $25 \%$ for samples A, B, and C respectively. According to British Soil Classification Systems (BSCS), soil sample $A$ is classified as a clayey sand, SCI (Clay of low plasticity), sample B as sandy clay of intermediate plasticity, CIS and sample $C$ as clay of high plasticity, $\mathrm{CH}$. According to American Association of State Highway and Transport Officials, AASHTO, sample $A$ is classified as A-2-5, sample B as A-2-7, and sample $C$ as A-7-6.

The chemical compositions of the three samples further show that they are lateritic soils with silica alumina ratio of about 2 . There are no presence of sulphates and carbonates, but with the presence of kaolinite predominant in samples A and B. Also, substantial amount of organic matter was found in sample $\mathrm{C}$.

\subsection{Moisture Density Relations}

The results of compaction tests on the samples show that Maximum Dry Density (MDD) for the soils ranged 
from $1.80 \mathrm{Mg} / \mathrm{m}^{3}$ to $1.70 \mathrm{Mg} / \mathrm{m}^{3}$, while the Optimum Moisture Content (OMC) ranged from $12.3 \%$ to
$16.3 \%$. Table 2 shows the summary of test results for the asphalt emulsion treated samples.

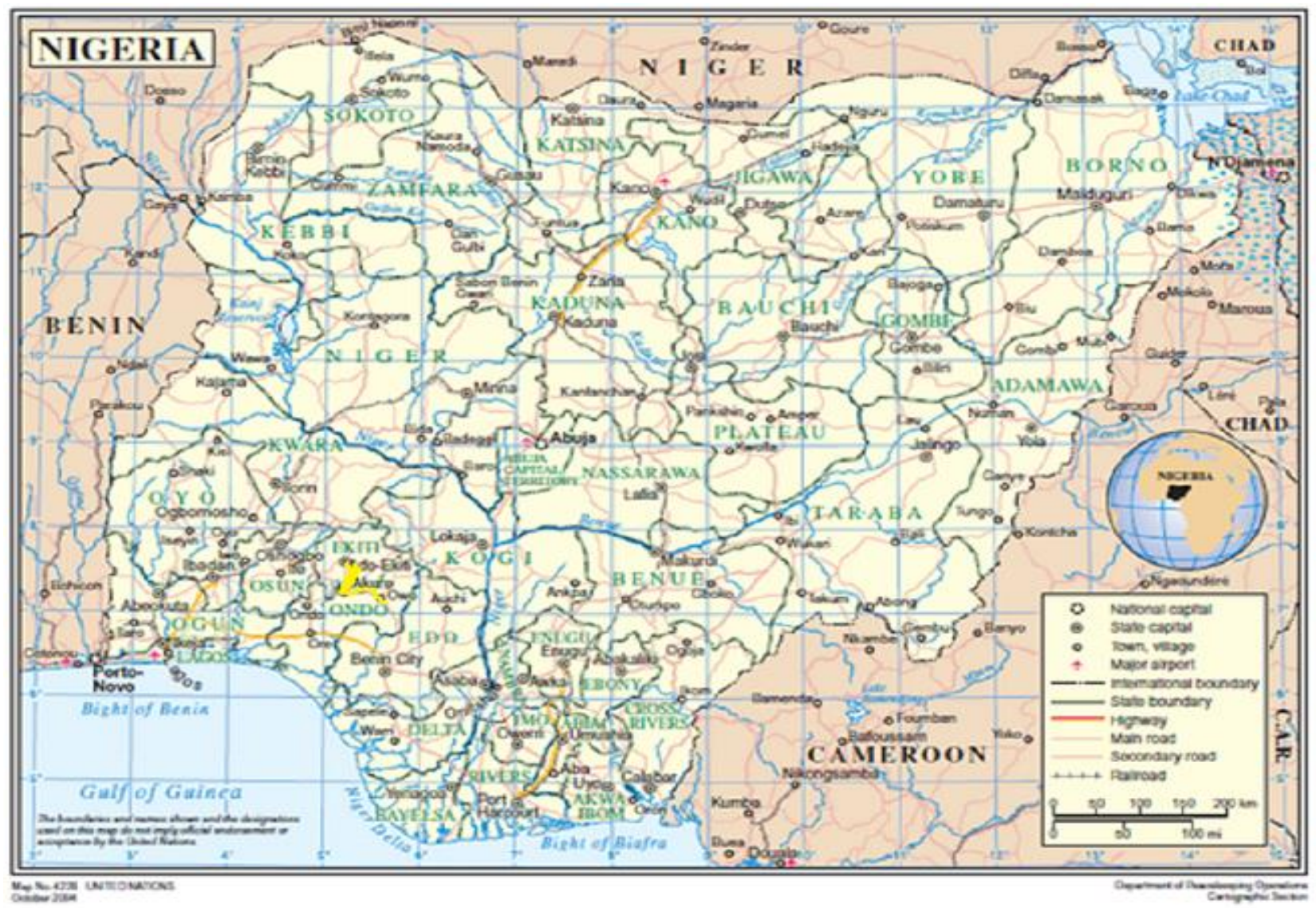

Figure 1: Map of Nigeria Showing Ondo and Ekiti State, Nigeria

Table 1: Characteristics of natural Soil Samples

\begin{tabular}{|c|c|c|c|}
\hline Soil + & 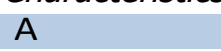 & B & C \\
\hline \multicolumn{4}{|l|}{ Textural composition \% } \\
\hline Gravel & 3.4 & 5.8 & 0.5 \\
\hline Sand & 62.4 & 62.2 & 44 \\
\hline Fine & 34.2 & 32 & 55.5 \\
\hline \multicolumn{4}{|l|}{ Classifications: } \\
\hline $\begin{array}{l}\text { British Soil Classification System, } \\
\text { BSCS }\end{array}$ & $\begin{array}{l}\text { Very clayed } \\
\text { Sand }\end{array}$ & $\begin{array}{l}\text { Clay of intermediate } \\
\text { Plasticity }\end{array}$ & Highly Plastic Soil \\
\hline $\begin{array}{l}\text { American Association of State } \\
\text { Highways and Transport } \\
\text { Officials, AASHTO }\end{array}$ & $A-2-5$ & $A-2-7$ & $A-7-6$ \\
\hline \multicolumn{4}{|l|}{ Physical properties: } \\
\hline Liquid limit, \% & 31 & 46 & 55 \\
\hline Plastic limit, \% & 22 & 31 & 29 \\
\hline Plastic index, \% & 9 & 15 & 26 \\
\hline Max Dry Density, $\mathrm{Mg} / \mathrm{m}^{3}$ & 1.8 & 1.8 & 1.7 \\
\hline Optimum Moisture Contents, \% & 12.3 & 15.3 & 16.3 \\
\hline \multicolumn{4}{|l|}{ Chemical Composition: } \\
\hline $\mathrm{pH}$ & 5.6 & 5.4 & 4.8 \\
\hline $\mathrm{S}_{\mathrm{i}} \mathrm{O}_{2}$ & 56.81 & 56 & 50.5 \\
\hline $\mathrm{AlO}_{3}$ & 26.22 & 26.11 & 30.93 \\
\hline $\mathrm{Fe}_{2} \mathrm{O}_{3}$ & 0.88 & 0.1 & 0.11 \\
\hline
\end{tabular}


Table 2: Summary Results of Asphalt- Emulsion Treated Soil Samples

\begin{tabular}{|c|c|c|c|c|c|c|}
\hline $\begin{array}{l}\text { Asphalt- Emulsion } \\
\text { Content \% }\end{array}$ & $\begin{array}{l}\text { OMC } \\
\%\end{array}$ & $\begin{array}{l}\mathrm{MDD} \\
\mathrm{Mg} / \mathrm{m}^{3}\end{array}$ & $\begin{array}{l}\text { CBR, } \\
\%\end{array}$ & $\begin{array}{l}\text { UCS, } 7 \text { DAYS } \\
\mathrm{MN} / \mathrm{m}^{2}\end{array}$ & $\begin{array}{l}\text { UCS, } 14 \text { DAYS } \\
\mathrm{MN} / \mathrm{m}^{2}\end{array}$ & $\begin{array}{l}\text { UCS, } 28 \text { DAYS } \\
\mathrm{MN} / \mathrm{m}^{2}\end{array}$ \\
\hline \multicolumn{7}{|c|}{ SAMPLE A } \\
\hline 0 & 12.3 & 1.8 & 20 & 0.85 & 1 & 1.20 \\
\hline 2 & 15.8 & 1.8 & 76 & 1.61 & 1.72 & 1.80 \\
\hline 4 & 15.4 & 1.86 & 110 & 2.2 & 2.3 & 2.50 \\
\hline 6 & 16 & 1.76 & 140 & 3 & 3.6 & 4.10 \\
\hline 8 & 16.5 & 1.74 & 91 & 2 & 2.2 & 2.25 \\
\hline \multicolumn{7}{|c|}{ SAMPLE B } \\
\hline 0 & 15.3 & 1.8 & 18 & 0.5 & 0.72 & 0.85 \\
\hline 2 & 15.5 & 1.78 & 45 & 0.85 & 0.92 & 1.20 \\
\hline 4 & 15.8 & 1.76 & 70 & 2.09 & 2.35 & 2.45 \\
\hline 6 & 16 & 1.75 & 80 & 2.59 & 2.68 & 2.82 \\
\hline 8 & 16.1 & 1.72 & 60 & 1.95 & 2.10 & 2.35 \\
\hline \multicolumn{7}{|c|}{ SAMPLE C } \\
\hline 0 & 16.3 & 1.7 & 8 & 0.5 & 0.5 & 0.68 \\
\hline 2 & 16.1 & 1.63 & 12 & 0.5 & 0.56 & 0.69 \\
\hline 4 & 16 & 1.6 & 33 & 1 & 1.2 & 1.45 \\
\hline 6 & 16.2 & 1.59 & 40 & 1.5 & 1.6 & 1.80 \\
\hline 8 & 15.7 & 1.53 & 60 & 1.8 & 2 & 2.44 \\
\hline
\end{tabular}

From the result, the OMC of sample $A$ increased from its natural value to $16.5 \%$ while the MDD decreased to $1.74 \mathrm{Mg} / \mathrm{m}^{3}$ at $8 \%$ emulsion content. The OMC of sample $B$ increased to $16.1 \%$ with the MDD reducing to $1.72 \mathrm{Mg} / \mathrm{m}^{3}$ at $8 \%$ emulsion content.

For soil sample $\mathrm{C}$, there is reduction in OMC and MDD as asphalt - emulsion content increases. The OMC and MDD decreased from their natural value to $15.7 \%$ and $1.53 \mathrm{Mg} / \mathrm{m}^{3}$ respectively at $8 \%$ emulsion content. Variations of MDD and OMC with asphalt emulsion contents of the sample are shown in Figures 2-4.

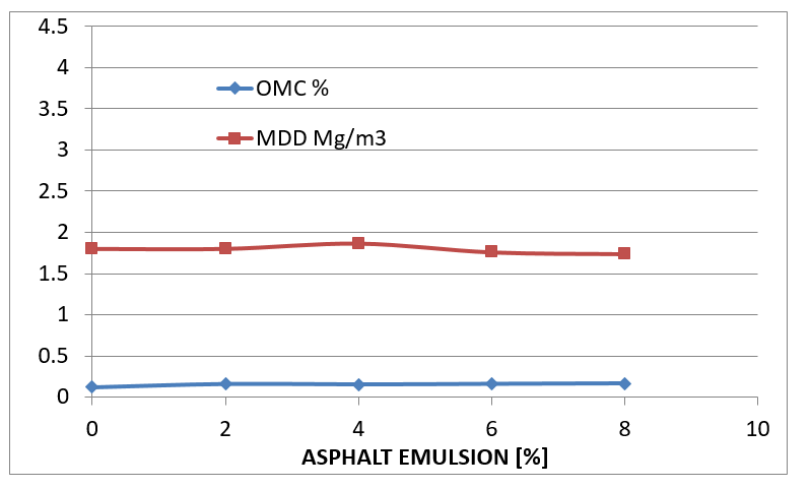

Figure 2: Variation of MDD and OMC with Asphalt Emulsion of Sample $A$.

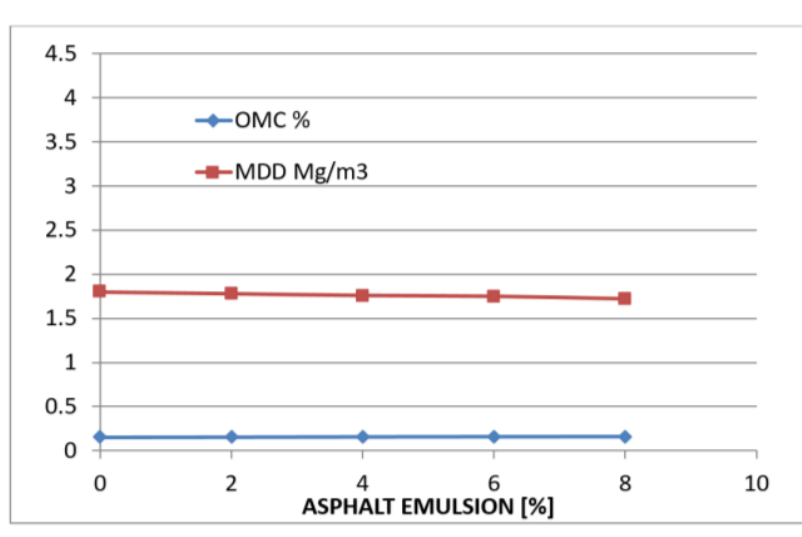

Figure 3: Variation of MDD and OMC with Asphalt Emulsion of Sample $B$.

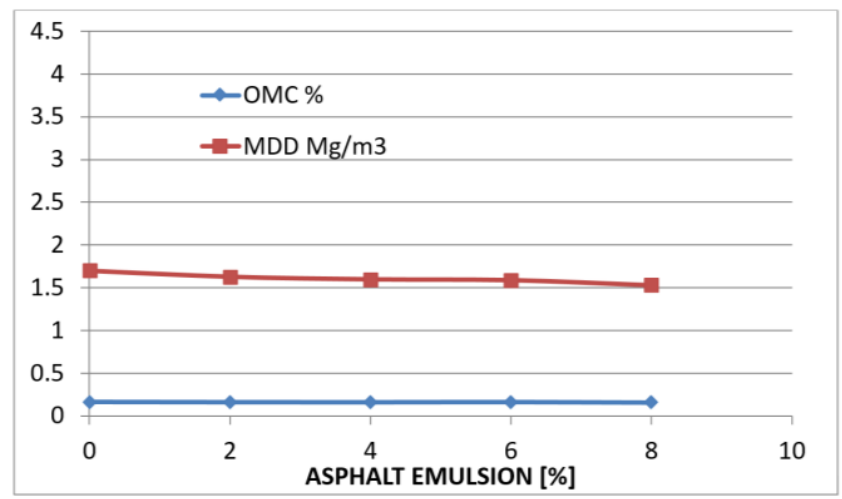

Figure 4: Variation of MDD and OMC with Asphalt Emulsion of Sample $C$. 


\subsection{California Bearing Ratio (CBR)}

The suitability of the natural samples for use as highway materials was also investigated using the California Bearing Ratio (CBR) test. The CBR value of the natural samples ranged from $8 \%$ to $20 \%$ as shown in Table 2.

Upon stabilization with asphalt-emulsion, the CBR values increased with increase in emulsion content to $110 \%$ and $140 \%$ at $6 \%$ emulsion content for sample A. For sample $B$, the maximum value of the $C B R$ is $80 \%$ also at $6 \%$ asphalt emulsion. On further addition of asphalt emulsion, the CBR values decreased showing that the optimum asphalt-emulsion content for treating soil type $A$ and $B$ is $6 \%$.

For a base material that requires a CBR value of 100 , the optimum emulsion content for soil type $A$ should be $4 \%$. Soil type $B$ is unsuitable as a base material but could be used as subbase, which requires a minimum CBR of $30 \%$.

For soil sample $C$, the CBR value also increased but with low percentage increment to a maximum CBR value of $60 \%$ at $8 \%$ emulsion content. The results of all the samples tested show increase in strength of asphalt emulsion treated soil samples.

Test results show that highly plastic clay soils do not respond favourably with asphalt emulsion. The results show low CBR values. This low CBR value is due to the presence of excessive amounts of clay, which made mixing and compacting difficult. This phenomenon is in accordance with the work of [4],which shows that materials containing high amounts of clay are not suitable for treatment with asphalt due to difficulty in mixing and rolling and high amount of emulsions required to achieve necessary water resistance. The variation of CBR with varied proportions of asphalt emulsion is shown in Figure 5.

\subsection{Unconfined Compressive Strength Test (UCS)}

Summary result of the unconfined strength test is as shown in Table 2 and replicated in Fig. 6. Testing was performed on remoulded samples at 7, 14 and 28 days to evaluate the effect of curing on the sample strength. The result shows an increase in strength of sample $A$ with age of curing from $0.85 \mathrm{MN} / \mathrm{m}^{2} 7$-day strength to $1.20 \mathrm{MN} / \mathrm{m}^{2} 28$-day strength; and from a 7-day strength of $0.50 \mathrm{MN} / \mathrm{m}^{2}$ to $0.85 \mathrm{MN} / \mathrm{m}^{2} 28$-day strength for sample B. Sample C increased from a 7day strength of $0.41 \mathrm{MN} / \mathrm{m}^{2}$ to a 28 -day strength of $0.68 \mathrm{MN} / \mathrm{m}^{2}$
The results show strength increase with increase in emulsion content up to $6 \%$, and for $8 \%$ emulsion content, a decrease in UCS was noticed for soil samples $A$ and $B$. For soil sample $A$, the UCS increased to maximum at 7 and 28 - day strength values of 3.0 $\mathrm{MN} / \mathrm{m}^{2}$ and $4.1 \mathrm{MN} / \mathrm{m}^{2}$ for $6 \%$ emulsion content but later reduced to $2.0 \mathrm{MN} / \mathrm{m}^{2}$ and $2.25 \mathrm{MN} / \mathrm{m}^{2}$ for $8 \%$ emulsion contents respectively.

The value of UCS for sample $B$ at $6 \%$ emulsion was $2.59 \mathrm{MN} / \mathrm{m}^{2}$ at 7 -day and $2.82 \mathrm{MN} / \mathrm{m}^{2}$ at 28 day. This later reduced to $1.95 \mathrm{MN} / \mathrm{m}^{2}$ and $2.35 \mathrm{MN} / \mathrm{m}^{2} 7$ and 28 - day strength at $8 \%$ emulsion content. Sample $\mathrm{C}$ had Increase in its natural UCS value from 0.41 $\mathrm{MN} / \mathrm{m}^{2} 7$ days to a maximum of $2.44 \mathrm{MN} / \mathrm{m}^{2} 28$ - day strength at $8 \%$ emulsion content.

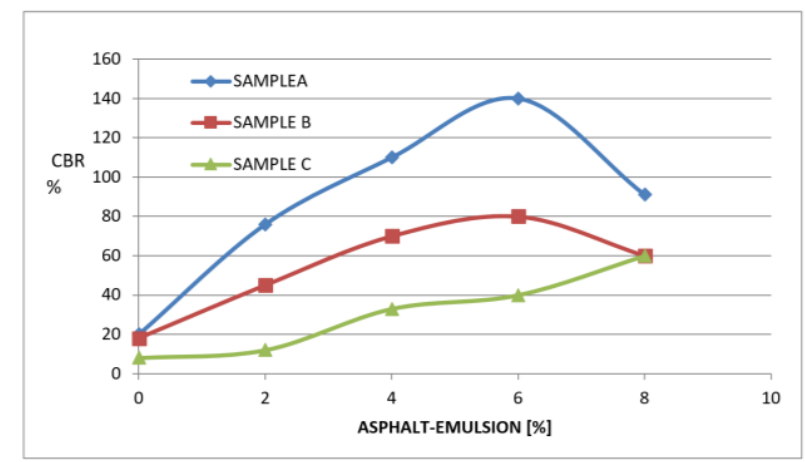

Figure 5: Variation of CBR with Asphalt - Emulsion for Sample $A, B$ and $C$

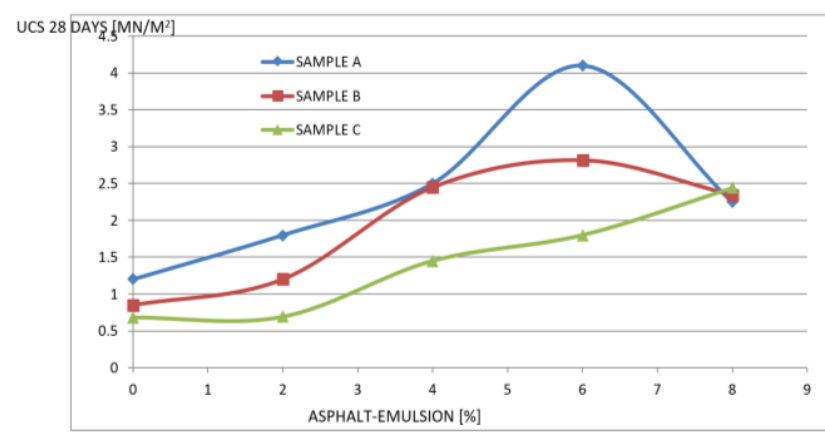

Figure 6: Variation of UCS with AsphaNIt - Emulsion for Sample A, B and C

\section{CONCLUSION AND RECOMMENDATIONS}

This investigation has shown that treatment of lateritic soil samples with asphalt-emulsion led to improvement on the engineering characteristics and strength of the soils, the rate of increase or degree of improvement achieved depends on the type of soil and the quantity of emulsion used. Asphalt - emulsion stabilization is not suitable for soils of high plasticity because of difficulty in 
mixing, and the high amount of emulsion required in achieving desired water resistance, thus making the economics of treatment unattractive. This shows that more quantity of emulsion would be required to stabilize this type of soil, and hence would bring about high construction cost. Also, age hardening of asphalt increases the strength of asphalt emulsion stabilized materials. To achieve best results for soils treated with asphalt emulsion, mixing in of the additive and compacting should be thoroughly carried out for uniform distribution within the mixture.

\section{REFERENCES}

[1] Ajayi, L. A. "The Laterites and Lateritic Soils of Nigeria, Geotechnical Practice in Nigeria, Int. Soc. of Soil Mechanics and Foundation Engineering, Nigerian Geotechnical Association, Nigerian Commemorative Publication, (1985): pp 7-15.

[2] American Virtual Productions Co. Specialty Emulsions History, Site-Rebuilt and Maintained, American Virtual Productions. Co, USA, 1997.
[3] British Lime Association, Improving Poor Ground Conditions, Lime and Cement Stabilization of Weak Soils, Aggregates Advisory Service, Digest No 058. 1997

[4] Coyne L. D. Emulsion Stabilization, Mix Design, Technical Paper No. 172, Chevron Asphalt Company, San Francisco, 1975.

[5] Coyne L. D. and Ripple R. M. "Technical Paper on Emulsified Asphalt Mix Design and Construction", Annual Meeting of the Association of Asphalt Paving Technologist. 1976.

[6] Koch Materials Company Emulsified Asphalt. Koch Pavement Solutions, USA, 2002.

[7] Transport Road Research Laboratory. Introduction to Soil Stabilization, Overseas Unit, Crow Thorne Berkshire, U K., 1937

[8] Oluyemi-Ayibiowu, B.D. "Assessment of Topshield as Stabilizing Agents for Some Nigerian Problem Soils", European International Journal of Science and Humanities, Vol. 1, Number6, 2015, pp 14-32 